\title{
Regulatory Roles of MicroRNAs in Diabetes
}

\author{
Juan Feng ${ }^{1}$, Wanli Xing ${ }^{1,2, *}$ and Lan Xie ${ }^{1,2, *}$ \\ 1 Medical Systems Biology Research Center, School of Medicine, Tsinghua University, Beijing 100084, China; \\ fengjuansdu@126.com \\ 2 National Engineering Research Center for Beijing Biochip Technology, Beijing 102206, China \\ * Correspondence: wlxing@tsinghua.edu.cn (W.X.); xielan@tsinghua.edu.cn (L.X.); \\ Tel.: +86-10-6277-3427 (W.X.); +86-10-6279-5218 (L.X.)
}

Academic Editor: Martin Pichler

Received: 17 August 2016; Accepted: 9 October 2016; Published: 17 October 2016

\begin{abstract}
MicroRNAs (miRNAs), a class of endogenous small noncoding RNAs in eukaryotes, have been recognized as significant regulators of gene expression through post-transcriptional mechanisms. To date, $>2000$ miRNAs have been identified in the human genome, and they orchestrate a variety of biological and pathological processes. Disruption of miRNA levels correlates with many diseases, including diabetes mellitus, a complex multifactorial metabolic disorder affecting $>400$ million people worldwide. miRNAs are involved in the pathogenesis of diabetes mellitus by affecting pancreatic $\beta$-cell functions, insulin resistance, or both. In this review, we summarize the investigations of the regulatory roles of important miRNAs in diabetes, as well as the potential of circulating miRNAs as diagnostic markers for diabetes mellitus.
\end{abstract}

Keywords: miRNAs; diabetes; $\beta$-cell function; insulin resistance; circulating miRNAs

\section{MicroRNAs (miRNAs) and Diabetes}

Diabetes mellitus is a progressive metabolic disease that is characterized by high blood sugar and is a great threat to human health. According to the World Health Organization, there are currently $>400$ million people suffering from diabetes worldwide, and that number will reach 552 million by 2030 [1]. Diabetes was first reported by the ancient Egyptians nearly 3000 years ago [2]. In 1936, the distinction between type 1 diabetes (T1DM) and type 2 diabetes (T2DM) was clearly defined [3]. Among patients diagnosed with diabetes, T1DM accounts for $5 \%-10 \%$ with the other $\sim 90 \%$ having T2DM. T1DM is a form of diabetes mellitus in which not enough insulin is produced by islet cells in the pancreas and subsequently results in high blood sugar levels. However, the exact cause of T1DM is still unknown. In most cases, it is an autoimmune disease, a condition in which the immune system mistakenly attacks the insulin-producing cells in the pancreas. T1DM is mostly diagnosed in children, adolescents, or young adults [3]. T2DM is featured with high blood sugar, insulin resistance (IR), and relative deficiency of insulin. The occurrence of T2DM results from a combination of genetic, environmental, and behavioral risk factors [4]. Different from T1DM, T2DM is often adult onset.

MicroRNAs (miRNAs) are short, non-coding RNAs with a size of $22 \mathrm{nt}$ [5]. In most cases, miRNA acts as negative regulators at the post-transcriptional level by inhibiting mRNA translation or degrading the mRNA by complementary binding to its $3^{\prime}$-untranslated region ( $3^{\prime}$-UTR) via the seed sequence region at the $5^{\prime}$ end of the miRNA. miRNAs are estimated to affect approximately $30 \%$ of protein coding genes [6]. An aberrant expression of miRNAs interferes with both physiological and pathological processes.

Since the discovery of miRNAs, an increasing number of them have been found involved in diabetes mellitus pathogenesis [7]. Dysregulation of miRNA can lead to profound impairment of glucose metabolism [8]. miRNA expression profiles of various tissues (e.g., pancreas, adipose tissue, 
and liver) from T2DM patients or hyperglycemia animal models have been established in recent years and make it easier to uncover novel miRNA regulators in diabetes.

\section{2. miRNAs and Pancreatic $\beta$-Cells}

Pancreatic $\beta$-cells play a central role in glucose homeostasis through secretion of insulin [9]. Important miRNAs associated with pancreatic $\beta$-cell dysfunction are summarized in Table 1 . Generally, they affect $\beta$-cells through the regulation of cell survival and apoptosis, proliferation, differentiation, or function, especially insulin secretion.

To regulate $\beta$-cell survival and apoptosis, miRNAs usually function by targeting cell apoptosis-related genes, such as the pro-apoptotic gene Bax (full names of all gene symbols are summarized in Appendix Table A1) and the anti-apoptotic gene $B c l-2$ [10,11]. For example, Belgard et al. show that overexpression of the miR-200 family in mice is sufficient to induce $\beta$-cell apoptosis and lethal T2DM through indirect activation of the pro-apoptotic genes Trp53 and Bax [12], while elevated miR-34a promotes MIN6 cell apoptosis by directly binding to the 3'-UTR of the anti-apoptotic gene $B c l-2$ [13].

In $\beta$-cell proliferation, some miRNAs play positive roles, while other miRNAs exhibit negative effects. One of the most important miRNA regulators is miR-375, which is highly expressed in both human and mouse pancreatic $\beta$-cells and is indispensable in maintaining normal pancreatic $\beta$-cell mass. Mice lacking miR-375 (375KO) display decreased pancreatic $\beta$-cell mass as a result of impaired proliferation, and further analysis demonstrates that miR-375 works by targeting a number of growth-inhibiting genes and is required for $\beta$-cell proliferation [14]. For example, Cadm1, as the direct target gene of miR-375, negatively regulates the G1/S transition and represses cell growth in various cancer cells lines [15]. Similar protective effects have already been reported for miR-181a because the reduction of $m i R-181 a$ in the islets of young rats also impairs $\beta$-cell proliferation [16]. Besides, miR-17 could promote $\beta$-cell proliferation through directly targeting Menin, which plays a crucial role in the regulation of gene transcription, cell cycle and apoptosis, in several mouse models and MIN-6 cells [17]. Consistently, it is reported that $m i R-17 / 92$, a miRNA cluster expressed in multiple tissues, also promotes pancreatic $\beta$-cell proliferation and adaption under stress conditions, further confirming the positive role of miR-17 in $\beta$-cell proliferation [18]. Other pancreatic $\beta$-cell proliferation regulators include miR-24, which is highly expressed in pancreatic $\beta$-cells, further upregulated in the islets of genetic fatty $\mathrm{db} / \mathrm{db}$ mice, and inhibits $\beta$-cell proliferation and insulin secretion by binding to two maturity-onset diabetes of the young genes, Hnf1 $\alpha$ and Neurod1. Meanwhile, the expression of miR-24 increased from 2.0- to 3.5-fold in 8- and 12-week-old db/db mice, showing an increase with the aging of $\mathrm{db} / \mathrm{db}$ mice [19]. Further, $m i R-29 a$ suppresses cell proliferation in INS-1E cells, leading to decreased glucose-stimulated insulin secretion of $\beta$-cells [20].

In the field of $\beta$-cell differentiation, the capacity of human pluripotent stem cells (hPSCs) to differentiate into insulin-producing cells (IPCs) makes them a promising in vitro model to study the regulatory roles of miRNAs in $\beta$-cell differentiation. Accordingly, the differentiation of hPSCs in vitro displays four stages: formation of definitive endoderm (0-4 days), induction of pancreatic progenitor cells (PPCs) (5-9 days), expansion of PPCs (10-15 days), and formation of IPCs (16-25 days). Based on this model, specific miRNAs have been proposed to modulate the process of directing hPSC differentiation toward islet-like cell clusters. Dynamic expression of miRNAs during the differentiation of human embryonic stem cells into islet-like cell clusters has been quantified, and four islet-specific miRNAs ( $m i R-7, m i R-375, m i R-34 a$, and $m i R-146 a$ ) exhibit distinct expression patterns during this process. Among them, miR-375 and miR-7 increase from day 4, peak on day 8 , and then decline until the end of differentiation. In contrast, $m i R-146 a$ declines throughout the differentiation process, and $m i R-34 a$ expression is reduced initially, followed by restoration on day 21 . The following analysis reveals that $m i R-375$ directly targets $H N F 1 \beta$, and overexpression of miR-375 downregulates the protein level of HNF1 $\beta$, while miR-7 directly targets $P A X 6$, and overexpression of miR-7 decreases the expression level of PAX6 [21]. Later studies have also proven that miR-7 and miR-375 are essential 
for pancreatic $\beta$-cell differentiation and development [22], and in vitro forced expression of miR-7 or $m i R-375$ helps to differentiate hPSCs into IPCs $[23,24]$. In addition, a number of other miRNAs, including miR-30d, let-7e, $m i R-21, m i R-9$, and $m i R-376$, are also implicated in human pancreatic islet differentiation and development [25-27].

Aside from the above, many other miRNAs are involved in pancreatic function, especially insulin secretion (e.g., miR-375, -184, -33, -187, -29a, and -30a) [28-37]. For example, although miR-29 is mentioned above in regard to its role in regulating $\beta$-cell proliferation, it has also been shown in multiple reports to negatively regulate insulin secretion by directly targeting St $x$ - $1 a$, a t-SNARE protein involved in insulin exocytosis [31], and Mct1, which may affect insulin secretion [32]. miR-124a is increased in type 2 diabetic human pancreatic islets and negatively regulates insulin secretion by directly targeting the GTPase Rab27a [33] and Foxa2 [34], which contribute to $\beta$-cell dysfunction in T2DM. Taken together, miRNAs and their target genes constitute a complex regulatory network in pancreatic $\beta$-cell functions, and the dysregulation of miRNAs may lead to diabetes mellitus.

Table 1. Principle microRNAs (miRNAs) involved in pancreatic $\beta$-cell function.

\begin{tabular}{|c|c|c|c|c|c|}
\hline Cell Processes & miRNA & Putative Targets & Cells or Tissues Studied & Species & References \\
\hline \multirow{3}{*}{$\beta$-cell survival/apoptosis } & $m i R-577$ & $F g f-21$ & INS-1 cells & rat & [11] \\
\hline & $m i R-200 a / b / c$ & - & islets of diabetic mice & mouse & [12] \\
\hline & $m i R-34 a$ & $B c l-2$ & MIN-6 cells & mouse & [13] \\
\hline \multirow{5}{*}{$\beta$-cell proliferation } & $m i R-375$ & Cadm1 & islets of miR-375 KO mice; INS-1E cells & mouse; rat & {$[14,15]$} \\
\hline & $\operatorname{miR}-181 a$ & Pdgfra & 3- and 12-month-old rat islets & rat & {$[16]$} \\
\hline & $\operatorname{miR}-17$ & Menin & MIN-6 cells & mouse & [17] \\
\hline & $m i R-24$ & Hnf1 $\alpha ;$ Neurod 1 & islets of obese mice & mouse & [19] \\
\hline & $\operatorname{miR}-29 a$ & - & INS-1E cells & rat & [20] \\
\hline \multirow{9}{*}{$\beta$-cell differentiation } & $m i R-375$ & HNF1 $\beta$ & hPSCs differentiated IPCs & human & [21] \\
\hline & miR-7 & PAX6 & hPSCs differentiated IPCs & human & [21] \\
\hline & $m i R-34 a$ & - & hPSCs differentiated IPCs & human & [21] \\
\hline & $\operatorname{miR}-146 a$ & - & hPSCs differentiated IPCs & human & [21] \\
\hline & miR-30d & RFX6 & hPSCs differentiated IPCs & human & [25] \\
\hline & let-7e & $R F X 6$ & hPSCs differentiated IPCs & human & [25] \\
\hline & $m i R-21$ & SOX6;RBJ & pancreatic progenitor cells & human & [26] \\
\hline & $m i R-9$ & - & human fetal islets & human & [27] \\
\hline & $\operatorname{miR}-376$ & - & human fetal islets & human & [27] \\
\hline \multirow{8}{*}{ Insulin secretion } & $m i R-375$ & Mtpn & MIN-6 cells & mouse & [28] \\
\hline & $m i R-184$ & Ago 2 & MIN-6 cells & mouse & [29] \\
\hline & $m i R-7 a$ & - & $\beta$-cells of diabetic mice & mouse & [30] \\
\hline & $m i R-29 a$ & Stx-1a;Mct1 & rat islets; mouse islets & rat; mouse & {$[31,32]$} \\
\hline & $m i R-187$ & HIPK3 & human islets from T2DM patients & human & [33] \\
\hline & $m i R-30 a$ & B2; NeuroD1 & rat islets and INS- 1 cells & rat & [34] \\
\hline & miR-124 & Rab27a; Foxa 2 & human islets; MIN-6 cells & human; mouse & {$[35,36]$} \\
\hline & miR-33 & $A b c a 1$ & mouse islets; MIN-6 cells & mouse & [37] \\
\hline
\end{tabular}

\section{3. miRNAs and Insulin Resistance (IR)}

IR refers to the impaired cellular response to insulin and the inability of normal amounts of insulin to achieve normal glucose homeostasis, which is a hallmark of T2DM. In this process, the insulin signaling pathway plays a central role. It is a highly complicated network that is initiated by insulin binding to the insulin receptor (INSR) on the cell surface, followed by the insulin receptor substrate launching downstream signaling cascades including phosphoinositide 3-kinase (PI3K), AKT serine/threonine kinase (AKT), and glucose transporter 4 (GLUT4). This process is illustrated in Figure 1. A growing body of evidence indicates that IR is associated with defects in insulin signaling. Notably, miRNAs may link insulin signaling and IR. 


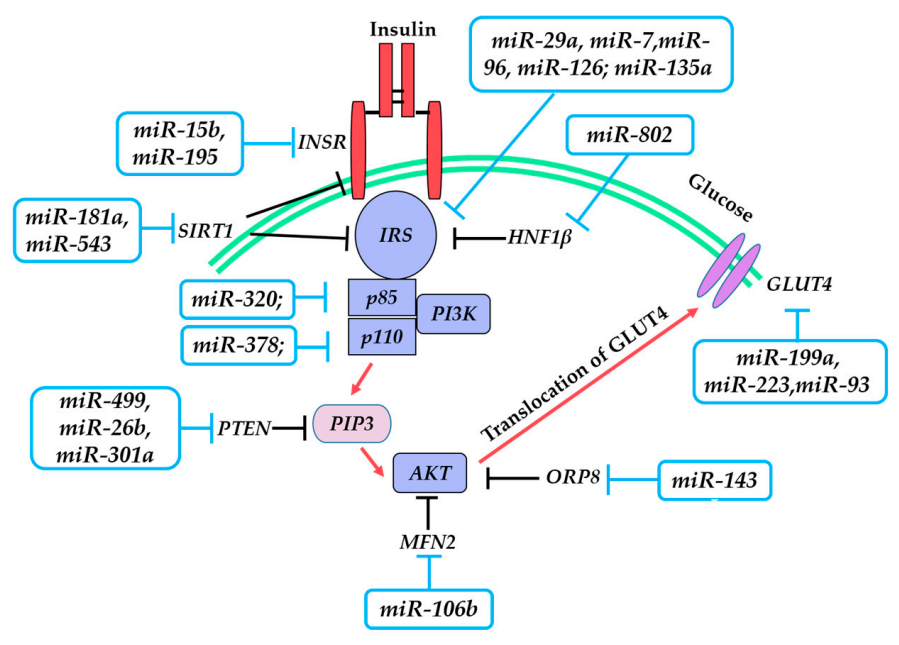

Figure 1. Major protein cascade and miRNAs in insulin signaling pathway. Red arrow-activation; $\mathrm{T}$ arrow-direct inhibition (blue); indirect inhibition (black). Abbreviations: INSR-insulin receptor; IRS—insulin receptor substrate; PI3K—phosphoinositide 3-kinase; SIRT1—sirtuin 1; PTEN-phosphatase and tensin homolog; PIP3-phosphatidylinositol 3,4,5-triphosphate; MFN2-mitofusin 2; AKT-AKT serine/threonine kinase; ORP8—oxysterol binding protein like 8; HNF1 $\beta$-hepatocyte nuclear factor 1- $\beta$; GLUT4-glucose transporter 4.

\subsection{Insulin Receptor (INSR)}

The ligand-receptor interaction is the first step of insulin signaling. Mice lacking the INSR gene suffer from hyperglycemia and hyperinsulinemia, and a large number of studies reveal a decrease in INSR in T2DM patients [38]. These findings support the importance of INSR for maintaining insulin sensitivity. Previous studies also demonstrate that $m i R-195$ and $m i R-15 b$ are both increased in the livers of obese T2DM model animals, accompanied by the downregulation of INSR, and further analysis confirms the direct binding of these miRNAs to the $3^{\prime}$-UTR of INSR, resulting in impairment of insulin signaling in hepatocytes [39,40].

\subsection{Insulin Receptor Substrate 1/2 (IRS-1/2)}

Insulin receptor substrate 1 (IRS-1) serves as the key molecule in the insulin signaling pathway in peripheral tissues by transmitting the signals from the INSR to the downstream enzymes. The IRS-1 expression level is lower in the skeletal muscle of obese-type T2DM mice and humans, indicating that the downregulation of IRS-1 is associated with IR and T2DM. In saturated fatty acids and high fat diet-induced insulin-resistant L6 myocytes, miR-29a expression is increased and represses IRS-1 expression via the direct targeting of the $3^{\prime}$-UTR of IRS-1 [41]. Similarly, in another cellular IR model (C2C12 myoblasts pretreated with fatty acids), overexpression of miR-7 downregulates IRS-1 expression via a direct interaction through binding to its $3^{\prime}$-UTR [42]. In IR resulting from mitochondrial dysfunction, significant upregulation of miR-96 is found in SK-Hep1 cells and, consequently, impairs insulin signaling through targeting the $3^{\prime}$-UTR of IRS-1 [43]. In maternal diet-induced obesity of offspring and IR in later life, miR-126 plays a negative role via targeting IRS-1 [44].

Aside from the miRNAs that directly bind to IRS-1, a class of miRNAs indirectly inhibits the expression of IRS-1. For example, in livers and adipose tissues of diet-induced obesity mice, overexpression of miR-103/107 negatively regulates insulin signaling by targeting Cav-1, a caveolae protein that activates insulin signaling by stabilizing the interaction between caveolae and IRS-1. Thus, enhanced miR-103/107 levels are concomitant with a decreased stability of IRS-1 [45].

Insulin receptor substrate 2 (IRS-2) is the alternative substrate of the INSR in IRS-1-deficient conditions. In skeletal muscle C2C12 cells, miR-135a targets Irs-2 by binding to its $3^{\prime}-\mathrm{UTR}$, and this interaction negatively regulates insulin signaling [46]. 


\subsection{Phosphoinositide 3-Kinase (PI3K)/AKT Serine/Threonine Kinase (AKT)}

PI3K is an indispensable kinase downstream of IRS-1 in the insulin signaling pathway. In response to the signal from IRS, PI3K is activated and leads to phosphorylation of AKT. PI3K consists of the regulatory subunit P85 and the catalytic subunit P110. The latter exists in two main isoforms in non-leukocytotic cell types, namely, P110 $\alpha$ and P110 $\beta$. Many IR effects are attributed to PI3K. For instance, miR-378 inhibits insulin signaling by targeting $p 110 \alpha$ in hepatocytes of ob/ob mice [47], and miR-320 decreases insulin sensitivity in 3T3-L1 adipocytes by targeting the $p 85$ unit of PI3K [48].

The product of PI3K activation is phosphatidylinositol 3,4,5-triphosphate (PIP3), and PTEN negatively regulates PI3K signaling by dephosphorylating PIP3. Therefore, miRNAs targeting PTEN such as $m i R-499, m i R-26 b$, and $m i R-301 a$ are beneficial for improving insulin sensitivity [49-51].

\subsection{Glucose Transporter 4 (GLUT4)}

Activation of PI3K/AKT induces the translocation of GLUT4 from intracellular vesicles to the plasma membrane. As the last step in the insulin signaling pathway, GLUT4-mediated glucose uptake plays a crucial role in maintaining glucose homeostasis. GLUT4 can be directly inhibited by miR-199a and $m i R-93 / 223$ in skeletal muscle and adipose tissue, respectively, which consequently has a negative impact on insulin sensitivity [52-54].

In addition to miRNAs regulating key proteins in insulin signaling, they may represent another crucial regulatory layer in regulating insulin sensitivity. miR-143a, miR-802, and miR-181a/543 affect hepatic insulin signaling by targeting Oxysterol binding protein like 8 (Orp8), Hepatocyte nuclear factor $1-\beta$ (Hnf1 $\beta$ ), and Sirtuin 1 (SIRT1), respectively [55-58]. miR-106b expression closely correlates with skeletal muscle IR by binding to the 3'-UTR of Mitofusin 2 (Mfn2) [59]. Principle miRNAs involved in IR are summarized in Table 2.

Table 2. Principle miRNAs involved in insulin resistance (IR).

\begin{tabular}{|c|c|c|c|c|c|}
\hline $\begin{array}{c}\text { Cell } \\
\text { Processes }\end{array}$ & miRNA & $\begin{array}{c}\text { Putative } \\
\text { Targets }\end{array}$ & Cells or Tissue Studied & Species & References \\
\hline \multirow{23}{*}{ IR } & $m i R-15 b$ & \multirow[b]{2}{*}{ INSR } & hepatocytes of diabetic mice & mouse & [39] \\
\hline & $m i R-195$ & & HepG2 cells & human & {$[40]$} \\
\hline & $m i R-29 a$ & \multirow{4}{*}{ IRS-1 } & L6 cells & rat & [41] \\
\hline & $m i R-7$ & & C2C12 cells & mouse & [42] \\
\hline & $m i R-96$ & & SK-Hep1 cells & human & [43] \\
\hline & $m i R-126$ & & adipose tissue & human & [44] \\
\hline & $m i R-135 a$ & Irs-2 & $\mathrm{C} 2 \mathrm{C} 12$ cells & mouse & [46] \\
\hline & $m i R-378$ & \multirow[b]{2}{*}{ PI3K } & hepatocytes of $m i R-378 / 378 *$ knockout mice & mouse & [47] \\
\hline & $\operatorname{miR}-320$ & & 3T3-L1 cells & mouse & [48] \\
\hline & $\operatorname{miR}-199 a$ & \multirow{3}{*}{ GLUT4 } & L6 cells & rat & [52] \\
\hline & $m i R-223$ & & human differentiated adipocytes & human & [53] \\
\hline & $\operatorname{miR}-93$ & & subcutaneous adipose tissue & human & [54] \\
\hline & $m i R-499$ & \multirow{3}{*}{ PTEN } & NCTC 1469 cells; livers of db/db mice & mouse & [49] \\
\hline & $m i R-26 b$ & & human insulin-resistant viceral adipocytes & human & [50] \\
\hline & $m i R-301 a$ & & NCTC 1469 cells & mouse & [51] \\
\hline & \multirow{2}{*}{$\operatorname{miR}-143$} & \multirow{2}{*}{ Orp8 } & HL- 1 cells & mouse & [55] \\
\hline & & & livers of obese mice & mouse & [56] \\
\hline & \multirow{2}{*}{$\begin{array}{c}\text { miR-181a } \\
\text { miR-543 }\end{array}$} & \multirow[b]{2}{*}{ SIRT1 } & HepG2 cells & human & [57] \\
\hline & & & HepG2 cells & human & [57] \\
\hline & $m i R-29$ & Ppar $\delta$ & $\mathrm{C} 2 \mathrm{C} 12$ cells & mouse & [53] \\
\hline & miR-103/107 & Cav-1 & livers and adipose tissues of diet induced obesity mice & mouse & {$[45]$} \\
\hline & miR-802 & $H n f 1 \beta$ & Hepa1-6 cells & mouse & [58] \\
\hline & $\operatorname{miR}-106 b$ & $M f n 2$ & C2C12 cells & mouse & [59] \\
\hline
\end{tabular}

IR-Insulin resistance; $m i R-378 / 378 *-m i R-378$ and $m i R-378{ }^{*}$ are two mature microRNAs originate from opposite arms of the same pre-miRNA. An asterisk following the name indicates the mature species found at low levels in cells. 


\section{Systematic Analysis of miRNA-mRNA Regulatory Network in Diabetes}

It has been shown that a single miRNA is directly responsible for the repression of hundreds of proteins, and a protein coding gene can be modulated by more than one miRNA [60]. Construction of the interaction network of miRNAs and mRNAs will help to elucidate diabetes pathogenesis on a systematic level. To achieve this goal, high-throughput technologies such as sequencing or microarrays are applied, and bioinformatics analysis is used to integrate multiple-omics datasets. Our previous work established the miRNA-mRNA functional network in Goto-Kakizaki (GK) diabetic rats.

Using the pancreatic tissues from GK diabetic rats, we examined the mRNA and miRNA expression profiles by microarray analysis. A total of 19 miRNAs were significantly downregulated or upregulated in pancreas islets of GK diabetic rats compared with normal Wistar rats. By virtue of the existing target prediction databases, target gene candidates were selected for the 19 differentially expressed miRNAs. As mentioned above, miRNAs regulate gene expression through mRNA degradation or translational repression. Thus, we assumed that there would be a negative correlation between miRNA expression and its target mRNA expression level. The predicted target genes were compared with the transcriptome data, and only those miRNA-mRNA pairs displaying opposite expression patterns were further included. In this way, 13 novel miRNAs (including miR-150, miR-497, and $m i R-344-3 p$ ) were found to show differential expression patterns between GK diabetic rats and normal Wistar rats for the first time, providing more new potential targets for research on T2DM. miRNA-mRNA pairs such as let-7f-collagen were identified in the study, which may have pivotal functions in pathogenesis and the development of diabetes, meriting further study [61].

Similarly, Tyler et al. use an integrative miRNA-mRNA microarray approach to identify the regulatory network in adipose tissue of insulin sensitive (IS) and IR individuals. Seventeen miRNAs are differentially expressed in the IR vs. IS group, including 16 miRNAs downregulated in IR individuals, such as miR-30b, and miR-145. Correspondingly, the potential target genes of these miRNAs, i.e., ADAM22, MYO5A, LOX and GM2A for miR-145; ADAM22 for miR-30b, were upregulated in IR subjects [62].

Along with the high-throughput data generated from sequencing or microarrays, construction of miRNA-mRNA regulatory networks in diabetes will provide new drug or genetic therapeutic candidates of this disease from a systematic and comprehensive view. This will supplement the current knowledge of diabetes in a rapid way, but the identifications from in silico analyses need further validation by molecular studies.

\section{5. miRNAs as Type 2 Diabetes (T2DM) Markers and Its Complications}

Although the mechanism of T2DM is not definitively clear, and a total cure is still difficult, preventive interventions could be achieved based on early molecular diagnosis. Hence, it is of great significance to discover novel and reliable biomarkers that can predict the onset or progression of T2DM. Circulating miRNAs, as a novel group of miRNAs existing outside cells, have drawn much research interest. The unique expression patterns, stability in circulation, and non-invasiveness of circulating miRNAs make them promising biomarkers for the diagnosis and prognosis of cancers, cardiovascular diseases, and T2DM.

Circulating miRNAs can exist in various types of body fluids, such as serum, plasma, and urine. They are secreted by donor cells via incorporation into vesicles including exosomes, microvesicles, or apoptotic bodies. Increasing evidence has indicated the potential of circulating miRNAs as predicting markers for diabetes and its complications. Zhang et al. previously examined the expression of a panel of plasma miRNAs in three groups of people: normal individuals (fasting glucose, 4.8-5.2 mmol/L), T2DM-susceptible individuals (fasting glucose, $6.1-6.9 \mathrm{mmol} / \mathrm{L}$ ), and T2DM patients (fasting glucose, $\geq 7.0 \mathrm{mmol} / \mathrm{L}$ ). They found that miR-126 is the only miRNA whose expression is significantly reduced in susceptible individuals and T2DM patients compared with normal individuals, suggesting that plasma miR-126 may serve as a potential marker for the early prediction of susceptible 
individuals to T2DM [63]. If the miR-126 expression is found to be lower than 35 (relative quantification unit), the individual is likely to develop T2DM in the following two years [64]. Similarly, by comparing expression profiles of miRNAs in the plasma of patients with prediabetes and newly diagnosed T2DM, Yan et al. demonstrated plasma $m i R-1249, m i R-320 b$, and $m i R-572$ levels as potential biomarkers for early diagnosis of T2DM [65].

One large threat of T2DM for human health is its complications. Several lines of evidence indicate that circulating miRNAs can both indicate the onset of T2DM itself and possess pre-clinical significance for assessment of diabetic complications. For instance, diabetic nephropathy (DN) is one of the most serious complications of diabetes. Recently, a prospective case-control study showed that $m i R-21, m i R-29 a / b / c$, and $m i R-192$ reflect DN pathogenesis and could be of clinical significance to monitor and prevent DN advancement [66]. miR-21 was shown to suppress PTEN, a key modulator in DN [67]; miR-192 was shown to suppress ZEB2, which is responsible for controlling TGF- $\beta$-induced extracellular matrix proteins accumulating during DN [67], while miR-29c was shown to inhibit SPRY1, which involves albuminuria and kidney mesangial matrix accumulation in diabetic mice models [68]. Interestingly, another type of miRNA that may serve as a candidate marker for DN is urinary miRNAs. Aberrant urinary miR-320c, isolated from urinary exosomes, may impact the TGF- $\beta$ signaling pathway via targeting THBS1 and could be used as a novel candidate marker for disease progression in DN [69].

Coronary artery disease (CAD) is another complication of T2DM, and circulating miR-126 displays differential expression patterns in the plasma of T2DM patients, T2DM patients with CAD, and healthy subjects, suggesting the potential of circulating miR-126 as a biomarker for diabetic CAD [70].

\section{Concluding Remarks}

Since their first discovery in Caenorhabditis elegans in 1993, miRNAs have attracted increasing attention. As a class of short non-coding RNAs, miRNA shed new light into the understanding of the genome. Considerable progress has already been achieved in the research of the links between regulatory miRNAs and diseases such as cancers, neurological diseases, and diabetes. miRNAs play pivotal roles in the onset and development of diabetes by affecting pancreatic $\beta$-cell function, IR, or both. Research into miRNA functions systematically provides us with valuable information to delineate the complex regulatory networks between miRNAs and mRNAs. Moreover, studies in recent years confirm that miRNA exists both inside and outside cells. The exciting emergence of circulating miRNA implicates them as an attractive choice for non-invasive biomarkers for the diagnosis and prognosis of T2DM. As potential disease biomarkers, miRNAs exhibit convincing advantages: sensitivity, stability, non-invasiveness, and reproducibility. A number of miRNA candidate signatures have appeared, and clinical trials are underway to validate their effectiveness.

Acknowledgments: This work is supported by the grant of National Natural Science Foundation of China (Grant number 81200464) and the National Hi-Tech Program of China (No. 2012AA020101).

Author Contributions: Juan Feng performed an intensive literature review and wrote the manuscript; Wanli Xing and Lan Xie made substantial contributions to the conception and critically revised the manuscript. All authors proofread and approved the final manuscript.

Conflicts of Interest: The authors declare no conflict of interest.

\section{Appendix A}

Table A1. Gene symbol abbreviations and full names.

\begin{tabular}{cc}
\hline Gene Symbol Abbreviations & Gene's Full Names \\
\hline Bcl-2 & B-cell lymphoma-2 \\
Trp53 & transformation related protein 53 \\
Bax & BCL2 associated $X$, apoptosis regulator \\
Cadm1 & cell adhesion molecule 1 \\
Hnf1 $\alpha$ & hepatocyte nuclear factor 1 homeobox $A$ \\
\hline
\end{tabular}


Table A1. Cont.

\begin{tabular}{|c|c|}
\hline Gene Symbol Abbreviations & Gene's Full Names \\
\hline Neurod1 & neurogenic differentiation 1 \\
\hline$H N F 1 \beta$ & hepatocyte nuclear factor 1 homeobox $\beta$ \\
\hline PAX6 & paired box 6 \\
\hline Stx-1 & syntaxin 1 \\
\hline$R a b 27 a$ & Ras-related protein $R a b-27 A$ \\
\hline Foxa2 & forkhead box protein $A 2$ \\
\hline Fgf21 & fibroblast growth factor 21 \\
\hline Pdgfra & platelet-derived growth factor receptor, $\alpha$ polypeptide \\
\hline RFX 6 & regulatory factor X6 \\
\hline SOX 6 & sex determining region Y-box 6 \\
\hline Mtpn & myotrophin \\
\hline Ago2 & argonaute 2 \\
\hline Mct1 & monocarboxylate transporter 1 \\
\hline HIPK3 & homeodomain interacting protein kinase 3 \\
\hline Abcal & ATP binding cassette subfamily A member 1 \\
\hline INSR & insulin receptor \\
\hline IRS-1 & insulin receptor substrate-1 \\
\hline$I R S-2$ & insulin receptor substrate- 2 \\
\hline PI3K & phosphatidylinositol 3-kinase \\
\hline GLUT4 & glucose transporter member 4 \\
\hline PTEN & phosphatase and tensin homolog \\
\hline Orp8 & oxysterol binding protein like 8 \\
\hline SIRT-1 & sirtuin 1 \\
\hline$M f n 2$ & mitofusin 2 \\
\hline$A D A M 22$ & ADAM metallopeptidase domain 22 \\
\hline MYO5A & myosin $V A$ \\
\hline LOX & lysyl oxidase \\
\hline GM2A & GM2 ganglioside activator \\
\hline ZEB2 & zinc finger E-box binding homeobox 2 \\
\hline$T G F-\beta$ & transforming growth factor $\beta$ \\
\hline SPRY1 & sprouty homolog 1 \\
\hline THBS-1 & thrombospondin 1 \\
\hline
\end{tabular}

\section{References}

1. Olokoba, A.B.; Obateru, O.A.; Olokoba, L.B. Type 2 diabetes mellitus: A review of current trends. Oman Med. J. 2012, 27, 269-273. [CrossRef] [PubMed]

2. Ahmed, A.M. History of diabetes mellitus. Saudi Med. J. 2002, 23, 373-378. [PubMed]

3. Raghunathan, K. History of diabetes from remote to recent times. Bull. Indian Inst. Hist. Med. Hyderabad 1976, 6, 167-182. [PubMed]

4. Mark, A.A.; George, S.E.; Aaron, M. Type 1 diabetes. Lancet 2014, 383, 69-82.

5. Chen, L.; Magliano, D.J.; Zimmet, P.Z. The worldwide epidemiology of type 2 diabetes mellitus—Present and future perspectives. Nat. Rev. Endocrinol. 2011, 8, 228-236. [CrossRef] [PubMed]

6. Sekar, D.; Venugopal, B.; Sekar, P.; Ramalingam, K. Role of microRNA 21 in diabetes and associated/related diseases. Gene 2016, 582, 14-18. [CrossRef] [PubMed]

7. Cuperus, J.T.; Fahlgren, N.; Carrington, J.C. Evolution and functional diversification of MIRNA genes. Plant Cell 2011, 23, 431-442. [CrossRef] [PubMed]

8. Dey, N.; Das, F.; Mariappan, M.M.; Mandal, C.C.; Ghosh-Choudhury, N.; Kasinath, B.S.; Choudhury, G.G. MicroRNA-21 orchestrates high glucose-induced signals to TOR complex 1, resulting in renal cell pathology in diabetes. J. Biol. Chem. 2011, 286, 25586-25603. [CrossRef] [PubMed]

9. Horak, M.; Novak, J.; Bienertova-Vasku, J. Muscle-specific microRNAs in skeletal muscle development. Dev. Biol. 2016, 410, 1-13. [CrossRef] [PubMed] 
10. Melkman-Zehavi, T.; Oren, R.; Kredo-Russo, S.; Shapira, T.; Mandelbaum, A.D.; Rivkin, N.; Nir, T.; Lennox, K.A.; Behlke, M.A.; Dor, Y.; et al. MiRNAs control insulin content in pancreatic $\beta$-cells via downregulation of transcriptional repressors. EMBO J. 2011, 30, 835-845. [CrossRef] [PubMed]

11. Chen, X.Y.; Li, G.M.; Dong, Q.; Peng, H. MiR-577 inhibits pancreatic $\beta$-cell function and survival by targeting fibroblast growth factor 21 (FGF-21) in pediatric diabetes. Genet. Mol. Res. 2015, 14, 15462-15470. [CrossRef] [PubMed]

12. Zheng, Y.; Wang, Z.; Tu, Y.; Shen, H.; Dai, Z.; Lin, J.; Zhou, Z. miR-101a and miR-30b contribute to inflammatory cytokine-mediated $\beta$-cell dysfunction. Lab. Investig. 2015, 95, 1387-1397. [CrossRef] [PubMed]

13. Belgardt, B.F.; Ahmed, K.; Spranger, M.; Latreille, M.; Denzler, R.; Kondratiuk, N.; von Meyenn, F.; Villena, F.N.; Herrmanns, K.; Bosco, D.; et al. The microRNA-200 family regulates pancreatic $\beta$-cell survival in type 2 diabetes. Nat. Med. 2015, 21, 619-627. [CrossRef] [PubMed]

14. Lin, X.; Guan, H.; Huang, Z.; Liu, J.; Li, H.; Wei, G.; Cao, X.; Li, Y. Downregulation of Bcl-2 expression by miR-34a mediates palmitate-induced Min6 cells apoptosis. J. Diabetes Res. 2014, 258695. [CrossRef] [PubMed]

15. Poy, M.N.; Hausser, J.; Trajkovski, M.; Braun, M.; Collins, S.; Rorsman, P.; Zavolan, M.; Stoffel, M. MiR-375 maintains normal pancreatic $\alpha$ - and $\beta$-cell mass. Proc. Natl. Acad. Sci. USA 2009, 106, 5813-5818. [CrossRef] [PubMed]

16. Zhang, W.; Xie, H.Y.; Ding, S.M.; Xing, C.Y.; Chen, A.; Lai, M.C.; Zhou, L.; Zheng, S.S. CADM1 regulates the G1/S transition and represses tumorigenicity through the Rb-E2F pathway in hepatocellular carcinoma. Hepatob. Pancreat. Dis. Int. 2016, 15, 289-296. [CrossRef]

17. Lu, Y.; Fei, X.Q.; Yang, S.F.; Xu, B.K.; Li, Y.Y. Glucose-induced microRNA-17 promotes pancreatic $\beta$-cell proliferation through down-regulation of Menin. Eur. Rev. Med. Pharmacol. Sci. 2015, 19, 624-629. [PubMed]

18. Chen, Y.; Tian, L.; Wan, S.; Xie, Y.; Chen, X.; Ji, X.; Zhao, Q.; Wang, C.; Zhang, K.; Hock, J.M.; et al. MicroRNA-17-92 cluster regulates pancreatic $\beta$-cell proliferation and adaptation. Mol. Cell. Endocrinol. 2016, 437, 213-223. [CrossRef] [PubMed]

19. Zhu, Y.; You, W.; Wang, H.; Li, Y.; Qiao, N.; Shi, Y.; Zhang, C.; Bleich, D.; Han, X. MicroRNA-24/MODY gene regulatory pathway mediates pancreatic $\beta$-cell dysfunction. Diabetes 2013, 62, 3194-3206. [CrossRef] [PubMed]

20. Bagge, A.; Clausen, T.R.; Larsen, S.; Ladefoged, M.; Rosenstierne, M.W.; Larsen, L.; Vang, O.; Nielsen, J.H.; Dalgaard, L.T. MicroRNA-29a is up-regulated in $\beta$-cells by glucose and decreases glucose-stimulated insulin secretion. Biochem. Biophys. Res. Commun. 2012, 426, 266-272. [CrossRef] [PubMed]

21. Wei, R.; Yang, J.; Liu, G.Q.; Gao, M.J.; Hou, W.F.; Zhang, L.; Gao, H.W.; Liu, Y.; Chen, G.A.; Hong, T.P. Dynamic expression of microRNAs during the differentiation of human embryonic stem cells into insulin-producing cells. Gene 2013, 518, 246-255. [CrossRef] [PubMed]

22. Kredo-Russo, S.; Mandelbaum, A.D.; Ness, A.; Alon, I.; Lennox, K.A.; Behlke, M.A.; Hornstein, E. Pancreas-enriched miRNA refines endocrine cell differentiation. Development 2012, 139, 3021-3031. [CrossRef] [PubMed]

23. Shae, A.; Azarpira, N.; Karimi, M.H.; Soleimani, M.; Dehghan, S. Differentiation of human-induced pluripotent stem cells into insulin-producing clusters by microRNA-7. Exp. Clin. Transplant. 2015, 16, 121-128.

24. Nathan, G.; Kredo-Russo, S.; Geiger, T.; Lenz, A.; Kaspi, H.; Hornstein, E.; Efrat, S. MiR-375 promotes redifferentiation of adult human $\beta$-cells expanded in vitro. PLoS ONE 2015, 10, e0122108. [CrossRef] [PubMed]

25. Liao, X.; Xue, H.; Wang, Y.C.; Nazor, K.L.; Guo, S.; Trivedi, N.; Peterson, S.E.; Liu, Y.; Loring, J.F.; Laurent, L.C. Matched miRNA and mRNA signatures from an hESC-based in vitro model of pancreatic differentiation reveal novel regulatory interactions. J. Cell Sci. 2013, 126, 3848-3861. [CrossRef] [PubMed]

26. Bai, C.; Li, X.; Gao, Y.; Wang, K.; Fan, Y.; Zhang, S.; Ma, Y.; Guan, W. Role of microRNA-21 in the formation of insulin-producing cells from pancreatic progenitor cells. Biochim. Biophys. Acta 2016, 1859, $280-293$. [CrossRef] [PubMed]

27. Joglekar, M.V.; Joglekar, V.M.; Hardikar, A.A. Expression of islet-specific microRNAs during human pancreatic development. Gene Expr. Patterns 2009, 9, 109-113. [CrossRef] [PubMed]

28. Poy, M.N.; Eliasson, L.; Krutzfeldt, J.; Kuwajima, S.; Ma, X.; Macdonald, P.E.; Pfeffer, S.; Tuschl, T.; Rajewsky, N.; Rorsman, P.; et al. A pancreatic islet-specific microRNA regulates insulin secretion. Nature 2004, 432, 226-230. [CrossRef] [PubMed] 
29. Tattikota, S.G.; Rathjen, T.; Hausser, J.; Khedkar, A.; Kabra, U.D.; Pandey, V.; Sury, M.; Wessels, H.H.; Mollet, I.G.; Eliasson, L.; et al. MiR-184 regulates pancreatic $\beta$-cell function according to glucose metabolism. J. Biol. Chem. 2015, 290, 20284-20294. [CrossRef] [PubMed]

30. Latreille, M.; Hausser, J.; Stützer, I.; Zhang, Q.; Hastoy, B.; Gargani, S.; Kerr-Conte, J.; Pattou, F.; Zavolan, M.; Esguerra, J.L.; et al. MicroRNA-7a regulates pancreatic $\beta$-cell function. J. Clin. Investig. 2014, 124, 2722-2735. [CrossRef] [PubMed]

31. Gomes, P.R.; Graciano, M.F.; Pantaleão, L.C.; Rennó, A.L.; Rodrigues, S.C.; Velloso, L.A.; Latorraca, M.Q.; Carpinelli, A.R.; Anhê, G.F.; Bordin, S. Long-term disruption of maternal glucose homeostasis induced by prenatal glucocorticoid treatment correlates with miR-29 upregulation. Am. J. Physiol. Endocrinol. Metab. 2014, 306, E109-E120. [CrossRef] [PubMed]

32. Pullen, T.J.; da Silva Xavier, G.; Kelsey, G.; Rutter, G.A. MiR-29a and miR-29b contribute to pancreatic $\beta$-cell-specific silencing of monocarboxylate transporter 1 (Mct1). Mol. Cell. Biol. 2011, 31, 3182-3194. [CrossRef] [PubMed]

33. Locke, J.M.; da Silva Xavier, G.; Dawe, H.R.; Rutter, G.A.; Harries, L.W. Increased expression of miR-187 in human islets from individuals with type 2 diabetes is associated with reduced glucose-stimulated insulin secretion. Diabetologia 2014, 57, 122-128. [CrossRef] [PubMed]

34. Kim, J.W.; You, Y.H.; Jung, S.; Suh-Kim, H.; Lee, I.K.; Cho, J.H.; Yoon, K.H. MiRNA-30a-5p-mediated silencing of $\beta 2 /$ NeuroD expression is an important initial event of glucotoxicity-induced $\beta$-cell dysfunction in rodent models. Diabetologia 2013, 56, 847-855. [CrossRef] [PubMed]

35. Sebastiani, G.; Po, A.; Miele, E.; Ventriglia, G.; Ceccarelli, E.; Bugliani, M.; Marselli, L.; Marchetti, P.; Gulino, A.; Ferretti, E.; et al. MicroRNA-124a is hyperexpressed in type 2 diabetic human pancreatic islets and negatively regulates insulin secretion. Acta Diabetol. 2015, 52, 523-530. [CrossRef] [PubMed]

36. Baroukh, N.; Ravier, M.A.; Loder, M.K.; Hill, E.V.; Bounacer, A.; Scharfmann, R.; Rutter, G.A.; Van Obberghen, E. MicroRNA-124a regulates Foxa2 expression and intracellular signaling in pancreatic $\beta$-cell lines. J. Biol. Chem. 2007, 282, 19575-19588. [CrossRef] [PubMed]

37. Wijesekara, N.; Zhang, L.H.; Kang, M.H.; Abraham, T.; Bhattacharjee, A.; Warnock, G.L.; Verchere, C.B.; Hayden, M.R. MiR-33a modulates ABCA1 expression, cholesterol accumulation, and insulin secretion in pancreatic islets. Diabetes 2012, 61, 653-658. [CrossRef] [PubMed]

38. Stumvoll, M.; Goldstein, B.J.; van Haeften, T.W. Type 2 diabetes: Principles of pathogenesis and therapy. Lancet 2005, 365, 1333-1346. [CrossRef]

39. Yang, W.M.; Jeong, H.J.; Park, S.Y.; Lee, W. Saturated fatty acid-induced miR-195 impairs insulin signaling and glycogen metabolism in HepG2 cells. FEBS Lett. 2014, 588, 3939-3946. [CrossRef] [PubMed]

40. Yang, W.M.; Jeong, H.J.; Park, S.W.; Lee, W. Obesity-induced miR-15b is linked causally to the development of insulin resistance through the repression of the insulin receptor in hepatocytes. Mol. Nutr. Food Res. 2015, 59, 2303-2314. [CrossRef] [PubMed]

41. Yang, W.M.; Jeong, H.J.; Park, S.Y.; Lee, W. Induction of miR-29a by saturated fatty acids impairs insulin signaling and glucose uptake through translational repression of IRS-1 in myocytes. FEBS Lett. 2014, 588, 2170-2176. [CrossRef] [PubMed]

42. Li, Z.Y.; Na, H.M.; Peng, G.; Pu, J.; Liu, P. Alteration of microRNA expression correlates to fatty acid-mediated insulin resistance in mouse myoblasts. Mol. Biosyst. 2011, 7, 871-877. [CrossRef] [PubMed]

43. Jeong, H.J.; Park, S.Y.; Yang, W.M.; Lee, W. The induction of miR-96 by mitochondrial dysfunction causes impaired glycogen synthesis through translational repression of IRS-1 in SK-Hep1 cells. Biochem. Biophys. Res. Commun. 2013, 434, 503-508. [CrossRef] [PubMed]

44. Fernandez-Twinn, D.S.; Alfaradhi, M.Z.; Martin-Gronert, M.S.; Duque-Guimaraes, D.E.; Piekarz, A.; Ferland-McCollough, D.; Bushell, M.; Ozanne, S.E. Downregulation of IRS-1 in adipose tissue of offspring of obese mice is programmed cell-autonomously through post-transcriptional mechanisms. Mol. Metab. 2014, 3, 325-333. [CrossRef] [PubMed]

45. Trajkovski, M.; Hausser, J.; Soutschek, J.; Bhat, B.; Akin, A.; Zavolan, M.; Heim, M.H.; Stoffel, M. MicroRNAs 103 and 107 regulate insulin sensitivity. Nature 2011, 474, 649-653. [CrossRef] [PubMed]

46. Agarwal, P.; Srivastava, R.; Srivastava, A.K.; Ali, S.; Datta, M. MiR-135a targets IRS2 and regulates insulin signaling and glucose uptake in the diabetic gastrocnemius skeletal muscle. Biochim. Biophys. Acta 2013, 1832, 1294-1303. [CrossRef] [PubMed] 
47. Liu, W.; Cao, H.; Ye, C.; Chang, C.; Lu, M.; Jing, Y.; Zhang, D.; Yao, X.; Duan, Z.; Xia, H.; et al. Hepatic miR-378 targets $\mathrm{p} 110 \alpha$ and controls glucose and lipid homeostasis by modulating hepatic insulin signalling. Nat. Commun. 2014, 5, 5684-5695. [CrossRef] [PubMed]

48. Ling, H.Y.; Ou, H.S.; Feng, S.D.; Zhang, X.Y.; Tuo, Q.H.; Chen, L.X.; Zhu, B.Y.; Gao, Z.P.; Tang, C.K.; Yin, W.D.; et al. Changes in microRNA (miR) profile and effects of miR-320 in insulin-resistant 3T3-L1 adipocytes. Clin. Exp. Pharmacol. Physiol. 2009, 36, e32-e39. [CrossRef] [PubMed]

49. Wang, L.; Zhang, N.; Pan, H.P.; Wang, Z.; Cao, Z.Y. MiR-499-5p contributes to hepatic insulin resistance by suppressing PTEN. Cell. Physiol. Biochem. 2015, 36, 2357-2365. [CrossRef] [PubMed]

50. Xu, G.; Ji, C.; Song, G.; Zhao, C.; Shi, C.; Song, L.; Chen, L.; Yang, L.; Huang, F.; Pang, L.; Zhang, N.; Zhao, Y.; Guo, X. MiR-26b modulates insulin sensitivity in adipocytes by interrupting the PTEN/PI3K/AKT pathway. Int. J. Obes. 2015, 39, 1523-1530. [CrossRef] [PubMed]

51. Dou, L.; Wang, S.; Sui, X.; Meng, X.; Shen, T.; Huang, X.; Guo, J.; Fang, W.; Man, Y.; Xi, J.; et al. MiR-301a mediates the effect of IL-6 on the AKT/GSK pathway and hepatic glycogenesis by regulating PTEN expression. Cell. Physiol. Biochem. 2015, 35, 1413-1424. [CrossRef] [PubMed]

52. Yan, S.T.; Li, C.L.; Tian, H.; Li, J.; Pei, Y.; Liu, Y.; Gong, Y.P.; Fang, F.S.; Sun, B.R. MiR-199a is overexpressed in plasma of type 2 diabetes patients which contributes to type 2 diabetes by targeting GLUT4. Mol. Cell. Biochem. 2014, 397, 45-51. [CrossRef] [PubMed]

53. Chuang, T.Y.; Wu, H.L.; Chen, C.C.; Gamboa, G.M.; Layman, L.C.; Diamond, M.P.; Azziz, R.; Chen, Y.H. MicroRNA-223 expression is upregulated in insulin resistant human adipose tissue. J. Diabetes Res. 2015, 2015, 943659-943709. [CrossRef] [PubMed]

54. Chen, Y.H.; Heneidi, S.; Lee, J.M.; Layman, L.C.; Stepp, D.W.; Gamboa, G.M.; Chen, B.S.; Chazenbalk, G.; Azziz, R. MiRNA-93 inhibits GLUT4 and is overexpressed in adipose tissue of polycystic ovary syndrome patients and women with insulin resistance. Diabetes 2013, 62, 2278-2286. [CrossRef] [PubMed]

55. Blumensatt, M.; Greulich, S.; Herzfeld de Wiza, D.; Mueller, H.; Maxhera, B.; Rabelink, M.J.; Hoeben, R.C.; Akhyari, P.; Al-Hasani, H.; Ruige, J.B.; et al. Activin A impairs insulin action in cardiomyocytes via up-regulation of miR-143. Cardiovasc. Res. 2013, 100, 201-210. [CrossRef] [PubMed]

56. Jordan, S.D.; Krüger, M.; Willmes, D.M.; Redemann, N.; Wunderlich, F.T.; Brönneke, H.S.; Merkwirth, C.; Kashkar, H.; Olkkonen, V.M.; Böttger, T.; et al. Obesity-induced overexpression of miRNA-143 inhibits insulin-stimulated AKT activation and impairs glucose metabolism. Nat. Cell Biol. 2011, 13, 434-446. [CrossRef] [PubMed]

57. Kornfeld, J.W.; Baitzel, C.; Könner, A.C.; Nicholls, H.T.; Vogt, M.C.; Herrmanns, K.; Scheja, L.; Haumaitre, C.; Wolf, A.M.; Knippschild, U.; et al. Obesity-induced overexpression of miR-802 impairs glucose metabolism through silencing of Hnf1b. Nature 2013, 494, 111-115. [CrossRef] [PubMed]

58. Zhou, B.; Li, C.; Qi, W.; Zhang, Y.; Zhang, F.; Wu, J.X.; Hu, Y.N.; Wu, D.M.; Liu, Y.; Yan, T.T.; et al. Downregulation of miR-181a upregulates sirtuin-1 (SIRT1) and improves hepatic insulin sensitivity. Diabetologia 2012, 55, 2032-2043. [CrossRef] [PubMed]

59. Zhou, Y.; Gu, P.; Shi, W.; Li, J.; Hao, Q.; Cao, X.; Lu, Q.; Zeng, Y. MicroRNA-29a induces insulin resistance by targeting PPAR $\delta$ in skeletal muscle cells. Int. J. Mol. Med. 2016, 37, 931-938. [CrossRef] [PubMed]

60. Hu, X.; Chi, L.; Zhang, W.; Bai, T.; Zhao, W.; Feng, Z.; Tian, H. Down-regulation of the miR-543 alleviates insulin resistance through targeting the SIRT1. Biochem. Biophys. Res. Commun. 2015, 468, 781-787. [CrossRef] [PubMed]

61. Zeng, L.Q.; Wei, S.B.; Sun, Y.M.; Qin, W.Y.; Cheng, J.; Mitchelson, K.; Xie, L. Systematic profiling of mRNA and miRNA expression in the pancreatic islets of spontaneously diabetic Goto-Kakizaki rats. Mol. Med. Rep. 2015, 11, 67-74. [CrossRef] [PubMed]

62. Kirby, T.J.; Walton, R.G.; Finlin, B.; Zhu, B.; Unal, R.; Rasouli, N.; Peterson, C.A.; Kern, P.A. Integrative mRNA-microRNA analyses reveal novel interactions related to insulin sensitivity in human adipose tissue. Physiol. Genom. 2016, 48, 145-153. [CrossRef] [PubMed]

63. Zhang, T.; Lv, C.; Li, L.; Chen, S.; Liu, S.; Wang, C.; Su, B. Plasma miR-126 is a potential biomarker for early prediction of type 2 diabetes mellitus in susceptible individuals. BioMed Res. Int. 2013, 761617. [CrossRef] [PubMed]

64. Zhang, T.; Li, L.; Shang, Q.; Lv, C.; Wang, C.; Su, B. Circulating miR-126 is a potential biomarker to predict the onset of type 2 diabetes mellitus in susceptible individuals. Biochem. Biophys. Res. Commun. 2015, 463, 60-63. [CrossRef] [PubMed] 
65. Yan, S.; Wang, T.; Huang, S.; Di, Y.; Huang, Y.; Liu, X.; Luo, Z.; Han, W.; An, B. Differential expression of microRNAs in plasma of patients with prediabetes and newly diagnosed type 2 diabetes. Acta Diabetol. 2016, 53, 1-10. [CrossRef] [PubMed]

66. Chien, H.Y.; Chen, C.Y.; Chiu, Y.H.; Lin, Y.C.; Li, W.C. Differential microRNA profiles predict diabetic nephropathy progression in Taiwan. Int. J. Med. Sci. 2016, 13, 457-465. [CrossRef] [PubMed]

67. Li, J.Y.; Yong, T.Y.; Michael, M.Z.; Gleadle, J.M. Review: The role of microRNAs in kidney disease. Nephrology 2010, 15, 599-608. [CrossRef] [PubMed]

68. Long, J.; Wang, Y.; Wang, W.; Chang, B.H.; Danesh, F.R. MicroRNA-29c is a signature microRNA under high glucose conditions that targets Sprouty homolog 1 , and its in vivo knockdown prevents progression of diabetic nephropathy. J. Biol. Chem. 2011, 286, 11837-11848. [CrossRef] [PubMed]

69. Delić, D.; Eisele, C.; Schmid, R.; Baum, P.; Wiech, F.; Gerl, M.; Zimdahl, H.; Pullen, S.S.; Urquhart, R. Urinary exosomal miRNA signature in type II diabetic nephropathy patients. PLoS ONE 2016, 11, e0150154. [CrossRef] [PubMed]

70. Al-Kafaji, G.; Al-Mahroos, G.; Abdulla Al-Muhtaresh, H.; Sabry, M.A.; Abdul-Razzak, R.; Salem, A.H. Circulating endothelium-enriched microRNA-126 as a potential biomarker for coronary artery disease in type 2 diabetes mellitus patients. Biomarkers 2016, 11, 1-11. [CrossRef] [PubMed]

(c) 2016 by the authors; licensee MDPI, Basel, Switzerland. This article is an open access article distributed under the terms and conditions of the Creative Commons Attribution (CC-BY) license (http://creativecommons.org/licenses/by/4.0/). 